\title{
The principle of Reformed intertextual interpretation
}

\author{
Young Mog Song (Kosin University, Busan, South Korea) \\ University of Johannesburg
}

\begin{abstract}
There has been a growing interest in intertextuality as a hermeneutical category in contemporary current biblical studies. The texture of a particular text is thickened and its meaning extended by its interplay with other texts, especially when the reader recognizes that the repetition of similar phrases and subject matter form part of an integral whole. The concept of intertextuality in this article firstly challenges the traditional approach that assumes that there is one meaning in a text that can be deduced when the author's intention is determined. Secondly, it disagrees with the New Criticism in which only the autonomous text plays the dominant interpretive role. The reader is considered to be merely a passive consumer of the text. Thirdly, it differs from the poststructural/deconstructional way which declares "the death of the author".
\end{abstract}

\section{THE ETYMOLOGY OF INTERTEXTUALITY ${ }^{1}$}

In both contemporary literary criticism and current biblical studies there has been a growing interest in intertextuality as a literary and hermeneutical category. Intertextuality and the intertext ${ }^{2}$ are coinages in English formed under pressure from the French intertextualité. The Latin word is intertexo which means "to interweave" or "intertwine". Ever fond of word play, poststructuralist ${ }^{3}$ theories have mined the etymology of the word "text" - "a tissue, something woven" - for a metaphor to describe the phenomenon of intertextuality (Davis 2002:13). The Greek root of the Latin texo is the stem tek-, found in the aorist form (etekon) meaning "to beget offspring".

Intertextuality, like textuality, ${ }^{4}$ is a strategic concept whereby the intermingling of all texts, including the mental texts of readers, may be accomplished. This vast theoretical space is the site, in effect, of all cultural citations.

\footnotetext{
* This article is based Young Mog Song's doctoral dissertation, entitled "The principle of Reformed intertextual interpretation". The dissertation was prepared under the supervision of Prof Dr J A du Rand, University of Johannesburg.
} 
Intertext(uality) is a methodological field and cannot be said to exhaust all reality (Harty 1985:2-12).

\section{THE EPISTEMOLOGY OF INTERTEXTUALITY}

Theoretical methodological attitudes within the domain of theological studies might most successfully be analysed and evaluated by examining the epistemological suppositions from which they derive. Epistemological frames can never be emptied (Ryan 1985:3; 39). Accordingly, without the epistemological shift, in a strict sense, a methodological shift does not take place. ${ }^{5}$ And because of the epistemological contradiction, the combination of different methodologies at times seems to be difficult. ${ }^{6}$ As pointed out by Carroll (1993:76), more traditional approaches might talk about "echo", "influence", "borrowing", and "quotation", though, to be fair to the concept of intertextuality. ${ }^{7}$ In biblical studies much work has already been done on intertextual matters, though without calling these by such a name. As a matter of fact, intertextuality describes a number of phenomena that are very old, very common and remarkably well known. Therefore, it can be concluded that intertextuality does not cause a major paradigm shift in hermeneutics, even though it has its own hermeneutical peculiarities.

Intertextuality, although a term of relatively recent origin in literary theory, has accumulated a bewildering variety of definitions and uses (Polaski 1998:58). Currently, intertextuality is a fashionable term, but almost everybody who uses it understands it somewhat differently ${ }^{8}$ (for the plural concepts of intertextuality, see Jonker 1999:81-82; and for the related terms and their definition, see Mettinger 1993:261-262). Originally the term was conceived and used by a critical avantgarde as a form of protest against established cultural and social values (Plett 1991:3). Hence, Fox (2002:17), exemplifying the feminist poststructuralist Helene Cixous's feminine texts, delineates this fact as follows: a commitment to intertextuality is a commitment to difference and to becoming Other. The politics of intertextuality and the postmodern are radical and concerned with "resistance" and "change". According to Barthes (1915-1980) and Kristeva, intertextuality is a revolutionary gesture directed by the modern text against the closure of the signifier in bourgeois or representational discourse (see Morgan 1985:24).

The actual concept of intertextuality goes back to Julia Kristeva; but it was quickly taken over and reinterpreted by others (Nielsen 2000:17). According to the poststructuralist literary critic Julia Kristeva ${ }^{9}$ (1986:34), who systematically coined the term "intertextuality" with reference to the Russian formalist ${ }^{10}$ Michael M Bakhtin's (1895-1975) concept of "dialogic orientation", ${ }^{11}$ 
it contains a mosaic of citations or an absorption or transformation of other texts. Any text, according to her, is a network of traces of other texts and, in turn, forms part of a universe of corresponding texts. As a result, then, no text exists in a vacuum. Stated differently, all texts are embedded in a larger web of related texts. ${ }^{12}$ The texture of a particular text is thickened and its meaning extended by its interplay with other texts, especially when the reader recognises that the repetition of similar phrases and subject matter cues parts of an integral whole. Interpreters seek and find new meanings in earlier texts (cf Tull 1999:164; Wall 2001:218-219). Thus, intertextual understanding is inevitable. Accordingly, Fishbane (2000:39) distinguishes three stages of biblical intertextuality, namely, the proto-canonical stage, the canon-withinthe-canon stage (i.e. intra-canonical intertextuality), and the stage of the canonical corpus itself together with its post-canonical effects, asserting the significance of intertextuality as follows:

Intertextuality is the core of the canonical imagination, that is, it is the core of the creative imagination that lives within a self-reflexive culture shaped by an authoritative collection of texts. The main reason for this is that a canon presupposes the possibility of correlations among its parts, such that new texts may embed, reuse, or otherwise allude to precursor materials - both as a strategy for meaning-making, and for establishing the authority of a given innovation. Put in a nutshell, intertextuality ... is a form that literary creativity takes when innovation is grounded in tradition.

Yet the fact that among theorists of intertextuality a wide variety of uses and applications of the term intertextuality can be found implies that intertextual analysis is no more a value-free, innocent critical practice than, for example, source and redaction criticism. ${ }^{13}$

For the proper understanding of intertextuality, the historical development of intertextuality between the 1960s and the 1990s is relevant. As Hatina (1999:30-31) observes, in the late 1960s and early 70s, intertextuality was associated with an antagonism toward the contemporary hermeneutical struggle, characterised by a crisis of representation which could no longer guarantee meaning, centrality and reference. Intertextual analysis is an alternative strategy to studying literary texts that would serve as an antidote to historically oriented approaches. This shift from historicism, with its tracing of literary origins and sources of influence, to intertextuality marked a dramatically different approach to literary studies (Landwehr 2002:2). Though Kristeva's main emphasis was on language theory, the concept of intertextuality was inseparably connected with political idealism (see Kristeva, 
1986:2). ${ }^{14}$ The agenda was nothing less than the subversion of the bourgeois establishment through the empowerment of the reader/critic to resist and combat the literary and social tradition at large. Hence, intertextuality is closely aligned with deconstruction in which language serves as the ground of existence and the world emerges as infinite text. Moreover, the poststructuralist focus on the role of the reader creates immediate discord with the historical critic who focuses on the author and the written text.

In the 1980s, efforts to make intertextuality a more systemised concept were made on the basis of reflection on the demerits of Kristeva's usage of intertextuality, which was thought to be too broad and not a systemised concept. The results of these efforts are semiotic intertextual analysis and hermeneutic intertextual analysis (Mertens 1990:20).

In the 1990s, Phillips pointed out the undeveloped situation of intertextual research in the field of biblical interpretation. According to Phillips (1991:78-79), the usefulness of intertextuality as a conceptual category for illuminating various exegetical phenomena, such as textual citation, allusion, allegorical interpretation, typology, rhetorical and discourse structures, narrative structure, reader-response strategies, canonical and extra-canonical formation, and the like, has not been exploited by biblical exegetes in particular or, for that matter, by religionists in general. There is a conspicuous absence of a sustained theoretical reflection upon such matters as intertextuality and its practical importance for explaining the complexities and thickness of biblical texts. This situation seems not to have been changed, at least as far as the study of the Book of Revelation is concerned.

In the same vein as Kristeva, Barthes (1977:160-161; 1981:39), who distinguishes a "text" from a "work", argues that the metaphor of the text is that of the network (cf Patte 1995:95). A text, Barthes explains, is a new tissue of past citations. Bits of codes, formulae, rhythmic models, and fragments of social languages pass into the text and are redistributed within it, for there is always language before and around the text. Intertextuality, the condition of any text whatsoever, cannot, of course, be reduced to a problem of sources or influences. Epistemologically, the concept of intertext is what brings to the literary theory of the text the volume of sociality: the whole of language, anterior or contemporary, comes to the text. However, a "work", according to Barthes, refers to the image of an organism, which grows by vital expansion, by development. The intertextual in which every text is held, in itself the textbetween of another text, is not to be confused with the origin of the text. Intertextuality is a quotation without inverted commas, and asks of the reader a practical collaboration. Thus, in the intertextual analysis, the author may not 
come back in the text, and becomes a paper-author: his life is no longer the origin of his fiction.

At this point, Barthes, like most postmodern literary critics, less thinks of the role of an author at the cost of that of a reader. ${ }^{15}$ The present writer agrees with poststructuralists in their emphasis on the fact that literary texts, like biblical texts, are intertextual, but does not accept the claim that the role of the reader can be defined as that of an exclusive producer. Thus, the following classical statement is still valid in this paper: there is a text, a text has an author and this author writes for his readers. As a matter of fact, however, the role of reader in the process of interpretation has been ignored. As Voelz (1995:154-156) significantly maintains, a reader must be seen as a text. More accurately, the states, actions, hopes, fears, and knowledge of a reader's life-experience comprise a text. In other words, as readers read, they read not only the signs of a given text in intertextual relationship to obtain a meaning for that text, but they read also their own life-experiences as textual signs and relate them to the signs and to the meanings of those signs on the various levels which comprise the given text, to make sense of their own lifeexperiences as textual sign, that is to apply the text to themselves. No one reads in a vacuum without his/her intention of an application of the text to his/her life.

Drawing on Gadamer's notion of a fusion of horizons, ${ }^{16}$ Brawley (1995:6-8) distinguishes between the diachronic approach represented by historical criticism and the synchronic approach including intertextuality, arguing that whereas the conventional approach focuses on a diachronic relationship between the precursor (text) and the successor (text), from the perspective of intertextuality the new text and the precursor depend on each other holistically in a synchronic relationship. The conventional approach breaks the precursor and the successor apart by insisting on the historical and literary context of each. According to the criteria of intertextuality, the related question is no longer how faithful the repetition is to the original. Rather, a reference to an old text locates the modern interpreter in a tensive ambience of echoes between the two texts, and the question is how the two texts reverberate with each other. "Because of the intertextual cross-reference", Riffaterre (1987:381) avers, "Each intertextual reading is in fact a rereading, a revised interpretation of a preceding stretch of text".

Greimas and Courtés (1979:161) argue that a work is not created on the basis of the artist's vision but on the basis of other works opens up the possibility for a better understanding of the phenomenon of intertextuality. This phenomenon implies the existence of autonomous semiotic systems (or discourse) within which more or less explicit processes of construction, 
reproduction, or transformation of models take place. But in the case of John, the author of Revelation, it is clear that his God inspired vision is the primary source of his work. His intertextual knowledge is a second source, even though his vision and intertextuality frequently intertwine with each other.

In connection with the epistemology of intertextuality, Culler (1983:114118) indicates two sorts of intertextual presuppositions, maintaining that, indeed, it is not difficult to make comparisons between the "logical presuppositions" of linguistics and the "rhetorical and literary (or pragmatic) presuppositions" which are central to the process of reading literary works. There are many ways in which rhetorical or literary (or pragmatic) presuppositions are signaled and produced by elements or constructions that carry no logical presupposition. The rhetorical (or pragmatic) presuppositions are defined not by the relations between sentences like logical presuppositions but by the relation between utterance and situation of utterance: an utterance of a sentence pragmatically presupposes that its context is appropriate. Hence, Culler comes to the conclusion that two limited approaches to intertextuality are possible. The first is to look at the specific (logical) presuppositions of a given text, the way in which it produces a pretext, an intertextual space whose occupants may or may not correspond to other actual texts. The second enterprise, the study of rhetorical or pragmatic presupposition, leads to a poetics which is less interested in the occupants of that intertextual space which makes a work intelligible than in the conventions which underlie that discursive activity or space.

Chandler (2002:16) summarises some defining features which are useful for considering degrees of intertextuality: (1) reflexivity (how reflexive or self-conscious the use of intertextuality seems to be); (2) alteration (the alteration of sources); (3) explicitness (the specificity and explicitness of reference[s] to other text[s]); (4) criticality to comprehension (how important it would be for the reader to recognize the intertextuality involved); (5) scale of adoption (the overall scale of allusion/incorporation within the text); and (6) structural unboundedness (to what extent the text is presented or understood as part of or tied to a larger structure). If a text shows these six features clearly, the degree of its intertextuality is clearly evident.

Even though a wide variety of uses and applications of the term can be found among theorists of intertextuality, in this work the term intertextuality is used primarily with reference to the strategies used both by John to create Revelation and by his audiences to interpret the Book. To put it another way, the way in which the term intertextuality is used in this dissertation is that all literature is made up of previous writings and reflects the earlier works through citation, allusion, use of phrases and paraphrases of older books to create 
newer literature, references to earlier episodes, and even echoes of earlier familiar literature in the construction of the later frame. Consequently, the term intertextuality is used primarily with reference to the strategies used both by John to create Revelation (i e text production) and by his audiences to understand the Book (i e text reception). ${ }^{17}$ Thus, intertextuality is concerned with three aspects, namely, the author-oriented, text-oriented, and readeroriented theories $^{18}$ (cf Linton, 1993:11, 23, 32, 33). Therefore, the concept of intertextuality in this paper, firstly, challenges the traditional approach, which assumes that there is one meaning in a text that can be deduced when one determines the author's intention. ${ }^{19}$ Secondly, it disagrees with the New Criticism in which only the autonomous text plays the dominant interpretive role. ${ }^{20}$ The reader is considered to be merely a passive consumer of the text. Thirdly, it differs from the post-structural/deconstructional ${ }^{21}$ way which declares "the death of the author"22 (cf Linton 1993:11, 32). Although proclaimed as early as 1968, "the death of the author" (Barthes) did not actually occur in intertextual theory, for author and reader had, at least implicitly, always been a matter of consideration. To put it differently, one cannot proclaim the death of the author without proclaiming the death of the reader, because every author is a reader as well. And conversely, if s/he claims the existence of the reader, s/he must accept the author as well. The author of a text begins as reader of an earlier text (cf Plett 1991:26; Nielsen 1992:127). As Landwehr (2002:4) observes, scholars of America intertextual criticism generally ignore the "death of author" and stress on the importance of the author. ${ }^{23}$ Furthermore, intertextuality accords with the hermeneutical rule that "Scripture interprets Scripture". The intertextuality of the NT does not simply add a new and interesting angle to the historical-critical enterprise; it points exegetes towards a hermeneutical model in which OT and NT are "interactive (or intertexture) mediums of the word of the Lord" in the dynamic process by which the reader understands and then submits to the Bible (Wall 2000:546-547).

"Text-oriented" intertextual interpretation focuses on the intertextual relations motivated by the text. "Reader-oriented" ${ }^{24}$ intertextual interpretation focuses on idiosyncratically motivated relations, primarily associations which the reader, for whatever reasons, includes in the process of meaning constitution. "Author-oriented" 25 intertextual interpretation tries to reconstruct hypothetically what intention caused the author to use intertextual relations, with what background knowledge, under what premises and with what intention s/he selected and embedded into her/his text certain reference texts, for what reasons specific reference and marking strategies were used, with what motivation or intention entities were marked explicitly or implicitly, and so 
on. As a matter of fact, divine Authorship does not preclude a plurality of voices as the canonical text is produced and interpreted (Holthuis 1994:85-86; cf Phillips 2000:233).

The appropriateness of intertextual analysis is supported by the genre of the Book of Revelation. As Perrin (1983:126, 128, 135) has maintained, one of the literary characteristics of the Book of Revelation as an apocalyptic prophecy is the extensive quotation of previously existing texts. The apocalyptic writers constantly used and re-used, interpreted and reinterpreted, the sacred texts of their tradition, especially earlier apocalyptic texts. Apocalyptic envisages a more dynamic interaction between the past text and the present situation, whereby the text interprets the situation and the situation interprets the text, so that the text itself can be modified and rewritten. So an apocalyptic discourse is usually a mosaic of scriptural quotations and allusions, together perhaps with some reference to the experience of the writer and his community, generally couched in scriptural language. With regard to textuality in communication, Du Toit (1990:517-518) points out the important fact that "biblical science must not neglect the role of the text as the expression of the communicational meaning of the sender. To admit the polyvalence of text does not necessarily mean its omnivalence. The possibility of meaning of a text is subject to the fixed limitation from the extratextual situation, the intertextual context in which it stands and the intratextual encoding methods of the message itself. These combinations of life-context, intertext and intratext impose restrictions on the text understanding which makes meaningful communication really possible".

\section{THE CONSTITUTING/CONSTRAINING CRITERIA OF INTERTEXTUALITY}

What is problematic about current notions of intertextuality is not the huge scope of the boundaries which have increased, but the transposing of horizons of understanding into matrices which generate an infinite chain of semiotic effects. Actually, the reader should not be left to construct textual meaning without external or given constraints ${ }^{26}$ (Thiselton 1992:506). In fact, the identification of an intertext is an interpretation itself (cf Mettinger 1993:275).

The criteria which provide constraints for intertextual analysis can be outlined briefly as follows (Keesmaat 1994:34-35; cf Hays 1989:29-32; Van Wolde 1997:432-433): 
- Availability: ${ }^{27}$ Was the proposed source of echo available to original author and/or original audiences?

- Volume: To what degree is there explicit repetition of words ${ }^{28}$ or syntactical patterns? This also involves how distinctive or prominent the precursor text is within Scripture and how much rhetorical weight the echo receives in the book. Volume should be measured on the phraseological plane and on other levels, for example, the replication of the form, genre, setting, and plot of their precursor. If on the level of plot, for example, a character in the successor text repeats the experience of a character in the precursor, the criterion of volume is valid (cf Brawley 1993:437; 1995:14; Brodie 2001:110).

- Recurrence: How often does the author elsewhere cite or allude to the same scriptural passage?

- Thematic coherence: ${ }^{29}$ How well does the alleged echo fit into the line of argument the author is developing? Does it clarify or illuminate the author's discussion?

- Historical plausibility: Could the author have intended the suggested meaning? Could his/her audiences have understood it? Or, leaving the language of intentionality aside, is the suggested meaning plausible in the light of the plots which the intertext of the culture allows?

- History of interpretation: Have other readers, both critical and precritical, heard the same echoes?

- Satisfaction: Does the proposed reading make sense? Does it illuminate the surrounding discourse? Does it produce a satisfying account of the effect of intertextual relation for the reader?

- Socio-historical, cultural, and ideological setting and structure (cf Keesmaat, 1994:33): If it were not for the study of the socio-historical setting, as Schoors $(2000: 45,59)$ points out, the study of intertextuality would be a synchronic business which, in the end, means an ahistorical study. Such an approach does not belong to scientific discourse, but rather to homiletical discourse. A text, a phrase, or a motif that has been borrowed receives its full meaning only from the actual (social) context in which it has been adopted. 
These criteria should be taken into account simultaneously. According to Brawley (1995:13), among the above criteria for intertextuality, "availability" and "volume" are crucial. Availability is decisive if it means consciousness of the cultural repertoire without which readers cannot catch echoes. Beyond the above criteria, there are other signs pointing to an intertext beyond the text. "Ungrammaticalities" are clues for readers to move beyond the literal level of significance to an intertextual level. Ungrammaticalities are conflicts which form obstacles to a construal of meaning as if they were grammatical anomalies or deviations from normal definitions. Ungrammaticalities are textual patterns that cannot be understood with the sole help of context, grammar, lexicon, and descriptive systems. As readers detect ungrammaticalities, they move to a network of relationships beyond the explicit text and perceive meaning in the interplay between text and intertext.

Sanders (2001:19) is of the opinion that one of the most obvious constraints on a writer who echoes Scripture is the factor of "recognisability": for the reference to have authority the reader must be able to recognise that the paraphrase or echo was indeed from Scripture. In conclusion, without intertextuality, a literary work would simply be unintelligible, like speech in a language one has not yet learned (Jenny 1982:34). Using the abovementioned criteria of intertextuality, the question is no longer how faithful the repetition is to the original. Rather, the question is how the two (or more than two) texts reverberate with each other (cf Brawley 1993:430).

\section{THE VALIDITY OF INTERTEXTUALITY IN THE REFORMED HERMENEUTICS ${ }^{30}$}

Reformed hermeneutics in the $21^{\text {st }}$ century is not only aided by a number of methodologies ${ }^{31}$ but also challenged by them. ${ }^{32}$ The variety of interpretations of Scripture is owing to the variety of endowments and experience contained in the various biblical perspectives. Insofar as these differing perspectives are true, they are ultimately reconciled in God (Glodo 2000:151). If multiple hermeneutical methods do not permit unbridled speculation, they provide exegetes with an opportunity, ${ }^{33}$ not a crisis. A responsible and inclusive method, including author, text and reader-centred methods and synchronic and diachronic methods, is required (Combrink 1990:332-333). As Thomas (1999:46-50) avers, one of the great gains of literary approaches to the Bible, including intertextuality, must surely be a renewed interest in the final form rather than hypothetical earlier versions of the canonical text. Reader-oriented theories are a valuable corrective to any absolutist claims of objectivity for the text. However, the view that the readers endow the text with meaning implies the idolatrous position that the readers create the text in their own image. 
Exegetes can drastically curtail unbridled subjectivity in exegesis by executing competent diachronic and synchronic analysis (i e examining antecedent and contemporary factors) of both the historical and the literary contexts of any biblical text. ${ }^{34}$ Interaction between reader and text is not an end in itself (contra reader response).

As Vanhoozer (1998:134-135) correctly points out, intertextuality both confirms and challenges the traditional idea of canon. ${ }^{35}$ Canon confirms intertextuality by showing it at work. Reading the NT intertextually, listening in on the dialogue that occurs every time an OT passage is woven into the fabric of the NT, might possibly save Christianity from polytheism and anti-Semitism (Sanders 2001:24). NT texts refer directly and indirectly to certain OT texts. The books within the biblical canon form a "separate cognitive zone" and are "interrelated like the parts of a single book". The canon encourages a play of meaning but only within carefully prescribed boundaries. But intertextuality challenges and then explodes the idea of canon as a fixed text. It does so in two ways. First, intertextuality challenges the idea that a text has a self-same meaning. In consequence, meaning is always in the process of forming, deforming and reforming. Second, intertextuality challenges the idea that Scripture interprets Scripture, that is, the notion that the biblical texts should ultimately be read in the light of one another. Thus intertextuality is the free association of diverse voices, the centrifugal force that explodes the centripetal constraint of canon. Meaning is not something located in texts so much as something that happens between them. It is precisely because this "between" cannot be stabilised that intertextuality undermines determinacy of meaning. ${ }^{36}$ In consequence, from Vanhoozer's assessment it is clear that there are some constraints by which exegetes can prevent subjective and uncontrolled intertextuality. Hence, the socio-historical context of the author and the audience, the textual context, inner-biblical intertextuality, extracanonical intertextuality are all able to play the role of useful constraints.

Although there can be the matter of priority, reformed hermeneutics should pay proper and balanced attention to the three elements of the foci in the process of interpretation, namely the author, the text and the reader. ${ }^{37}$ Concerning the autonomy of the text, the role of the reader, and authorial intent, Silva's (1994:237-246) argument is relevant here:

For interpretation to take place, there must be an author, a text, and an interpreter (reader or hearer), and it is precisely this threepronged relationship that can create confusion. The theological perspective of the biblical authors is seldom expressed in explicit terms; rather, it is reflected in their composition of the text. Accordingly, close attention to the literary quality of narrative, even 
if considered in relative independence from its historical reference, can be of immense value in understanding the significance of the history which that narrative presents. In regard to the role of the reader, the danger is that, troubled by what appear to be extreme formulations, the exegetes may close their eyes to the invaluable contributions made by this movement. Whether they like it or not, readers can - and routinely do - create meanings out of the texts they read. While in certain cases the task of identifying what the biblical author meant is not the only legitimate way of proceeding, such a task is always legitimate and indeed must continue to function as an essential goal.

In connection with the validity of intertextuality in reformed hermeneutics, Adams (1990:13) indicates a significant point: the practice of basing a biblical theology not on biblical texts but on hypothetical ur-sources, oral stages, or on apocryphal material, misses the point of the modifier "biblical" or "reformed". The influence of historical criticism is to some extent simply inescapable for most interpreters, because historical criticism is involved with such fundamental tasks as translation and textual criticism. However, the strength of the greatest biblical theologies, after all, lies not in their historical analysis (though it may be rigorous), but in the theological penetration and insight of their construals of the Bible. From Adams's insistence it is evident that biblical intertextuality has priority and is more important than the intertextuality of noncanonical sources.

To define the position of reformed intertextual study, Plett's category should be given close attention here. Plett (1991:3-5) categorises attitudes towards intertextuality into three groups: (1) the progressives who try to cultivate and develop the revolutionary heritage of the originators of the new concept. Their representatives do not tire of quoting, paraphrasing and interpreting the writings of Bakhtin, Barthes, Kristeva, Derrida and other authorities. (2) The traditionalists who belong almost exclusively to the group of conventional literary scholars. Alerted by public reaction to the work of poststructuralists and deconstructionists, these scholars ask themselves whether the insights of the intertextuality debate can be applied profitably to their own concerns. (3) A third group emerges: the opposition to the new approach. Their basically negative attitude expresses itself in two different strategies of argumentation. The progressive, speculative ones are simply not understood; they are accused of subjectivity and irrationalism and an utter lack of scientificity. Yet even stronger is the opposition to the traditionalist, pragmatic variant. Anti-intertextualists do not tire of emphasising that they themselves have worked intertextually all along. The change in terminology did not bring about any substantial change. In Plett's three categories, the 
reformed intertextualist is a traditionalist who finds a profitable result for intertextuality for his/her own concerns, namely a constructive reformed interpretation of the Book of Revelation. Reformed intertextuality is not based on the linear communication model in which the sender delivers a message via the medium to the receiver, who is a passive consumer of the message. A circular or a spiral communication model, in which the sender, the medium, and the receiver are each unique contributors to the communication process, is the basis of intertextuality. This spiral communication model accords with hermeneutical epistemology (cf Thiselton 1999:167). ${ }^{38}$

A responsible intertextual exegesis involves not only a responsibility towards the possible intentions of an original author, but also a willingness to include (at least implicit or secondary) meanings that were not intended but which arise in the dialogue with earlier (and sometimes later) intertexts (Nielsen, 2000:31). As pointed out above, in reformed intertextual study the biblical intertextuality in general and the OT intertextuality in particular are the most important elements. Reformed intertextuality should be grounded in the coherence of Scripture as a whole. In this phase, the argument between Steve Moyise and Gregory K. Beale is illuminating. Moyise (1995:110-111) provides the first serious attempt to apply the postmodern ${ }^{39}$ hermeneutical perspective of intertextuality to the use of the OT in Revelation. Working inductively, he argues that the intertextual approach is appropriate to the study of Revelation. Moyise uses the of a fruit salad. In a fruit salad there are no more shiny apples, but pieces of apple mixed with other fruits and covered with syrup. While the connection remains between the apple on the tree and the apple in the fruit salad, one is struck more by the differences between the two forms of application than one is in the fruit-basket analogy. Thus, Moyise finds the "new meaning" of the OT in Revelation (cf Soulen \& Soulen, 2001:87). Furthermore, in contrast to Beale, whose decisive element of the correct interpretation lies in finding authorial intention, Moyise (2001a:40) contends: "I am suspicious of those who claim that there is but one correct way of reading Revelation". Actually, there are a number of important theories which have something to do with a proper understanding of Revelation. They can illuminate different aspects of the Book, just as the Four Gospels illuminate different aspects of Jesus.

G K Beale calls Moyise's approach into question in the most comprehensive single work ever written on the subject of allusions to the OT in Revelation. Beale develops the analogy of a basket of fruit to express his viewpoint. Based both on conservative Hirschian hermeneutics and the Christian-theistic biblical worldview, Beale (1998:51-52) argues that while an apple in a basket of fruit has been removed from its original context, it has not 
lost its identity as an apple. It has simply been placed in a new context. So when NT writers quote the OT, they are placing such texts in a new context and giving them "new significance" within that new context, but they are not altering what the original writer meant. Beale cites four presuppositions (Christ corporately represents Israel; history is a unified plan; the end-time has been inaugurated by Christ; Christ is the key to the OT) which he believes governed John's approach to Scripture. He then suggests that interpreters who agree with these presuppositions will conclude that John respects the original context of his allusions (see Moyise 2001a:37). Indeed, Beale opposes the "new meaning" of the OT in Revelation. Moreover, he insists that meaning derives solely from an author's intention (contra Moyise 2001a:35-36), not from the creative processes of readers. Beale (2001:32) asserts that, while he concedes that readers can "create" meaning, it is a meaning, implied at least by and partially derivative from authorial intent. If one goes further than this concession, then one places the reader in a sphere separated from all significant links to a text's original meaning, which appears to be Moyise's position. The ultimate goal of all readings is that exegetes' lives would glorify the divine Author of meaning. Although Beale's argument is reformed, if the reader's doxology is added his intertextual study is more embedded in reformed intertextuality. In his recent article on John's use of the OT, Paulien $(2001: 11,22)$ compares Moyise and Beale and concludes that they have brought to the topic two sides of a necessary dichotomy. Both a hermeneutic of suspicion and a hermeneutic of retrieval are needed, and provide a necessary balance, for interpretation (contra Beale 2001:32).

The presumed historical (i.e. diachronic) process by which the text came into being is important for a writer. As in historical criticism (esp. tradition, source, and redaction criticism), which focuses on writer or redactor, text productive intertextuality is essentially diachronic or historical in nature. ${ }^{40}$ Thus, the text components are in fact viewed as indices, that is, as signs that are directly and causally determined by earlier text. But in the case of text receptive intertextuality, the final text product, which is compared with other texts in synchronic relationships, is important. The principle of causality is then rejected; its place is taken by the principle of analogy. Words are not viewed as indexical signs but as iconic signs, which denote the principle that phenomena are analogous or isomorphic. Similar and different texts are explained as being indirectly related to each other and as having a similar or iconic quality or image in common (see Van Wolde 1997:430-431). In conclusion, the time has come for a change in reformed hermeneutics. As a postmodern methodology, intertextuality gives reformed hermeneutics a real opportunity to listen and learn from Scripture with a high view of the Bible. 
Reading Scripture dialogically through intertextuality provides rich lodes within Scripture that are rarely explored. Since Scripture is transcultural and intertextual in nature, all its parts have depths that can plumb the very essence of the human experiment (Sanders, 2001:25). ${ }^{41}$

\section{End Notes}

${ }^{1}$ According to Polaski (1998:58), intertextuality is not so much a methodology as a threoretical term; or, rather, a theoretical term which may give birth to several different methodologies. In the same vein, Paul (2000:259) says, "intertextuality, as an approach, does not provide a method for interpretation, so much as highlighting the importance of considering the relation between the new context and the old in interpreting allusion and citation". But as Clippinger (2001:190) holds, intertextuality refers to both a "method" of reading that juxtaposes texts in order to discover points of similarities and differences as well as the belief that all texts and ideas are part and parcel of a fabric of historical, social, ideological, and textual relations. On the other hand, intertextuality can be explained as a "mindset" in which a methodology is employed.

${ }^{2}$ In connection with this notion of intertextuality, Derrida's (1976:158) notorious statement "There is nothing outside the text" (or, literally translated: "There is no outside-text") does not imply that nothing exists except text, but rather that everything relevant to reading, to textual analysis, including the context, is contained within the intertext. In other words, it states that textuality pervades everything (cf Harty 1985:11; Degenaar 1995:12).

${ }^{3}$ Here, a brief explanation of the transition from structuralism to poststructuralism is helpful to understand intertextuality as a poststructural method. The theory of structuralism itself arose during the early part of the twentieth century as a critique of prevailing liberal humanist views about the nature of language and meaning. Previously in the study of literature, it had been assumed that both language and meaning were direct products of an author's mind. Structuralist theorists like Saussure and Lévi-Strauss challenged this assumption. They argued that the source of meaning in language and texts was not the author; instead, they proposed that meaning be understood as the product of preexisting, universal structures within language itself. Thus, structuralists typically seek to analyse all narratives as variations of universal narrative patterns. However, during the 1960s and 1970s, some philosophers and literary theorists had already begun challenging certain assumptions of structuralism. This critical challenge heralded the rise of "poststructuralism". While structuralists have insisted that all language has at its core a basic, universal structure that generates meaning, poststructuralists argue that this core, this basic structure, is illusory - it is only a false trace, the result of language's attempts to hide its own contradictions and incompleteness (see Davis 2002:11-12).

${ }^{4}$ The term "textuality", Degenaar (1995:11) explains, refers to the nature of being a text in a textual world in which signs are dynamically interrelated allowing for new connections to be made continually. At this stage, in addition, the definition of "text" in this work is necessary before further discussion on intertetxuality. Deconstruction views a text as an intertextual event. In the first place intertextuality refers to the interrelationships between texts in the normal sense of the word "text", as referring to the interweaving of signs in a book, article or poem. In the second place intertextuality also refers to the interrelationships between texts in the less common sense of the word "text" as referring to any object of understanding (for the seven different definitions of "text", see Degenaar 1995:7-10). In this paper, "(inter)text" primarily refers to the normal sense of written material. 
${ }^{5}$ Senekal (1999:73-77), who suggests Christ-centred sociology, accepts the fact that God is the ultimate causa sui and in control, and he tends to bring back the causa sui (on a human level) in explanations of human and social behavioural phenomena. A paradigm shift depends on exegetes not hermeneutical tools, because the major change occurs not so much in the tool, but in the user of the tool. With regard to the presupposition of reformed hermeneutics, in contrast to worldly irrationalism and worldly rationalism, hermeneutical salvation, like all other aspects of salvation, is by grace alone. Exegetes act with hermeneutical responsibility only because God has acted on them, through the Spirit of Christ (Jn 15:16; cf Poythress, 1999:222). Hence, Gulley (2000:208) recklessly and too frequently uses the term "paradigm shift", when he explains the latest cultural paradigm (e.g. narrative and reader-response theories) within the context of their growth out of the historical (e.g. historical criticism) and literary (e g canonical criticism, structuralism) paradigms. The change of locus of meaning from author to text to reader, according to Gulley, is also a paradigm shift.

${ }^{6}$ One example comes from the integration of the socio-scientific approach and the literary approach. In the actual world of NT critical practices, some socio-scientific and literary approaches are indeed complementary and can easily be merged into an integrated approach, while other socio-scientific interpretations are incompatible with literary and rhetorical interpretations and cannot be considered complementary. The reason is that the relationship between critical approaches in the NT studies is determined by prior epistemological and philosophical presuppositions that cause differences within approaches to precede those between approaches (see Craffert 1996:45). With regard to the possibility of integration of different methods, Erickson's (1993:123) remarks are pertinent: "There will need to be a genuinely philosophical basis to the hermeneutical work that is done. It is essential that hermeneuts understand that genuine ideational differences separate various hermeneutical systems. A given hermeneutic will need to be understood as part of a much larger system of thought, and that system will have to be carefully evaluated. ... The philosophical sophistication of different hermeneutical approaches is necessary for future hermeneutical works." In this regard, Heie (1996:148) is an exception in that his crossperspective conversation (or perspectivalism: as an epistemological assumption, the world is perceived, processed, and articulated with one or another perspective, and a perspective has the power to make sense out of the rawness of experienced life, even though it cannot be proven or absolutely established) and moderate postmodernism allow him to reach an epistemological integration between radically differing perspectives (or methodologies). Heie (1996:151) further suggests five ideals for cross-perspectival conversation: reciprocity and mutual recognition, inclusiveness, equal voice, humility and charity. But he seems to fail to demonstrate the concrete possibility of the integration of conflict epistemology.

${ }^{7}$ The following list of key concepts which are interconnected with intertextuality reveals that intertextual study is a multifaceted and elusive phenomenon indeed: quotation, source, influence, allusion, association, reminiscence, echo and reference. In addition, citing Laurent Jenny, Mettinger distinguishes "intertextuality proper" (when a text alludes to or redeploys an entire structure, a pattern of form and meaning from an earlier text) from "simple allusion" or "reminiscence" (when a text repeats an element from an earlier text, without referring to the original meaning in the original context; see Mettinger 1993:257).

${ }^{8}$ According to Sanders (2000:38), who sees the Bible as the dialogue between the OT and the NT, there are three principal ways in which the term "intertextuality" is used in the literature currently. It is used first to focus on the chemistry between two contiguous blocks of literature, large or small. A second use is the recognition that all literature is made up of previous literature and reflects the earlier through citation, allusion, use of phrases and paraphrases of older to create newer literature, references to earlier episodes, even echoes of earlier familiar literature in the construction of the later. The third use is the recognition that the reader is also a text and that reading is in essence an encounter between texts. In other words, the reader is a bundle of hermeneutics, as it were, engaging a text that is itself a bundle of hermeneutics. Since the NT itself was composed and shaped in the period of textual fluidity, one has to be quite discerning in locating modes of intertextuality (Sanders, 2001:19; for the interfaith dialogue between Judaism and Christianity on the basis of the canonical intertextuality see Sanders, 2001:14-16). In this paper, all three uses the word 
mentioned by Sanders are taken into consideration. Intertextuality has a broad sense as Aune explains: "intertextuality is a way of reading a text which sees it as a network of references to other texts, a phenomenon which may be approached at the levels of the word, the phrase and the sentence, but which becomes particularly evident in terms of larger textual units within a composition which has parallels or analogues in the constituent literary units of other texts. Intertextuality plays a central role in both the production and reception of texts. Texts are necessarily written and read in light of the familiarity which both authors and readers have with earlier texts" (Aune 1991:142-143).

${ }^{9}$ While Kristeva retains linguistic analysis as an essential tool of study, she feels the necessity to go beyond structuralist study, and even beyond semiotics as first conceived (Zepp 1982:85, 89). In her doctoral dissertation, Revolution in poetic language, Kristeva (1984:59-60) insisted that the term intertextuality denotes the transposition of one (or several) sign system(s) into another, but since this term has often been understood in the banal sense of "study of sources", she prefers the term "transposition" because it specifies that the passage from one signifying system to another demands a new articulation of the thetic - of enunciative and denotative positionality. Similarly, Plett (1991:20-23) introduces four transformations of intertextuality: (medial, linguistic, and structural) substitution, addition, subtraction, and permutation. Moyise (1995:111) is of the opinion that the task of intertextuality is to explore how the source text continues to speak through the new work and how the new work forces new meanings from the source text. In the 1980s in South Africa, W S Vorster (1988:120), for instance, urgently proposed the necessity of the intertextual study in Revelation in order to research the Book in a new perspective instead of source and redaction criticism. While the study of sources and influence of texts on other texts is the historical forerunner of intertextuality, Vorster $(1989: 19,26)$ draws the differences between studies based on intertextuality and redaktionsgeschichte: the main difference seems to be the concept "text". Viewing a text as a network of fragments of texts, which refer endlessly to other texts because of the absorption of other texts, is something totally different from studying the agreements and differences between a focused text and its sources. While redaktionsgeschichte focuses on the redactor and his activities, intertextuality takes seriously the fact that authors produce texts and that readers react to these texts by assigning meaning to them. Source-influence is not the focus point of intertextuality. In intertextuality meaning is assigned to the text by intertextual reading in accordance with the function of the intertexts of the focused text. In another place, Vorster (1993:394) goes on to delineate that "there is a total difference between an attempt where the NT is understood from the perspective of its "production", and an attempt where it is understood from the perspective of its "growth". The first approach (intertextuality) seriously considers that any allusion or quotation from another text forms an integral part of the new text. The latter (e g source criticism) regards the final text, which has relationships with precursor texts, as the result of a causal process." Desrosiers (2000:87-88) correspondingly sets forth the opinion that "meaning is woven not only by parts of a text interacting with one another, but through the interaction with the sum of all texts which belong to a specific culture as embodied in its various individuals and groups. It is much more than mere "source hunting". Source criticism has had the tendency to see the production of meaning in a very linear (diachronic) way, going from the source to the new document in which it is now included. Intertextuality, on the other hand, sees the interaction between source and text as something more interactive. Intertextuality, when used in its purest form, deals with transformation of meaning and transformation of reader".

${ }^{10}$ The Russian theoreticians emphasise the preserving functions of the intertext (quoting text). In contrast, French theoreticians see intertextuality as a decentralising and destabilising force. Explicit intertextuality can carry with it both "disruptive" and "reconstructive" features. This double movement of disruption and regeneration is precisely its raison d'être. (Boyarin 1987:540-541).

${ }^{11}$ The French critic Tzvetan Todorov has declared Bakhtin to be the twentieth century's greatest literary thinker. Bakhtin's original term "dialogic orientation" is now called "intertextuality". For Bakhtin (1981:426, 428), "dialogism" is the characteristic epistemological mode of a world dominated by heteroglossia which is the base condition governing the operation of meaning in any utterance. Everything means, is understood, as a part of a 
greater whole - there is a constant interaction between meanings, all of which have the potential of conditioning others. Which will affect the other, how it will do so and to what degree is what is actually settled at the moment of utterance. This dialogic imperative, mandated by the pre-existence of the language world relative to any of its current inhabitants, ensures that there can be no actual monologue. Bakhtin calls attention to three loci where some sort of dialogue is operative. The first is the existence of a variety of other, foreign, even competing utterances already present in the environment into which the text enters, that attach themselves to the subject about which the text wishes to speak; the second, an internal dialogism operating within the text as it responds to the utterances in its environment; and the third, the active, sometimes competing responses of the audience (see Tull 1999:167). In addition, as Van Wolde (1997:427) points out, two major differences are evident between Bakhtin and Kristeva (also see Duff 2002:61): (1) Bakhtin is not only concerned with the relationship between texts but also with the relationship between text and reality, while Kristeva restricts intertextuality to the relationship between texts. At the same time Kristeva extends the concept of text further so that reality also becomes a text. (2) Bakhtin looks from the perspective of one text to other texts, while Kristeva does not look from the text but from the intertext or "the book of the culture" of which a text forms a small part. These differences have become gradually bigger, because in the course of time the theories concerning intertextuality have been developed further into a more vague concept by French (post) structuralists and American postmodernists. However, according to R N Soulen and R K Soulen (2001:87), rather than to Bakhtin, whose influence arrived in the West only in the late $20^{\text {th }}$ century, some scholars point to an essay by T S Eliot (1919) as generative of studies loosely classifiable as intertextual in nature. Eliot noted that texts do not arise de novo but are dependent on, extend, and renew the language, symbolic worlds, and metaphors of texts that preceded and, in their interaction with new social conditions, generated them.

${ }^{12}$ With regard to the concept of a web, Beal (1992:22-23) argues: "The basic force of intertextuality is to problematise, even spoil, textual boundaries - those lines of demarcation which allow a reader to talk about the meaning, subject, or origin of a writing. Such borders, intertextuality asserts, are never solid or stable. Texts are always spilling over into other texts. No text is an isolated island". What makes intertextuality interesting, however, is that the shared webs of meaning and association that enable communication between people are never fully and completely shared (Tull 1999:165).

${ }^{13}$ Intertextuality is not a time-bound feature in literature and the arts. Nevertheless it is obvious that certain cultural periods incline to it more than others. In the postmodernist period, intertextuality is apparent in every section of culture: literature, film, art, architecture, music, photography, and so forth, even if it is interpreted in different ways (Plett 1991:26).

${ }^{14}$ Intertextuality is not some neutral literary mechanism but rather at root a means of ideological and cultural expression and of social transformation (Aichele \& Phillips 1995:9). In Kristeva's interpretation, one easily realises the political meaning of interpretation: "There are political implications inherent in the act of interpretation itself, whatever meaning that interpretation bestows. ... To give a political meaning to something is perhaps only the ultimate consequence of the epistemological attitude which consists, simply, of the desire to give meaning" (Kristeva 1982:78).

${ }^{15}$ In terms of content and even of form, intertext and theme may indeed coincide, but they differ radically from each other in terms of their impact on the "reader". In fact, a theme's impact can be quite independent of the reader's recognition of the theme. By contrast, intertextuality exists only when two texts interact. They cannot be an intertext without the reader's awareness of it (Riffaterre 1990:74-75).

${ }^{16}$ The fusion of horizons appears in many fields of contemporary hermeneutics. For example, as his book title "New horizons in hermeneutics" suggests, Thiselton (1992:1) argues that texts may enlarge the horizons of readers. When this occurs, horizons move and become new horizons. Reading may also produce transforming effects. Kim (1999:80-81), who combines postcolonial, feministic, deconstructional and intertextual interpretations for understanding Rev 17 , holds that reading the text, as a flesh-and-blood reader, is not a 
discovery or reconstruction of the latent meaning of the text, but a process, through which something is newly raised up by mutual dialogue between the text and the reader. The fusion of horizons runs parallel to the concept of Paul Ricoeur's (1984:78-80) refiguration (mimesis ${ }^{3}$ ). To Ricoeur, the horizon (or world) is the whole set of references opened by every sort of descriptive or poetic text the reader has read, interpreted and loved. The horizon of the text and the world of the reader interpenetrate one another through the fusion of horizons; the reader belongs to both the experiential horizon of the work imaginatively, and the horizon of its action concretely. Drawing on Tracy's concept of "analogical imagination", Conradie (1992:104) holds that interpretation is the search for similarities-in-differences between the text and the reader, and that in the act of interpretation, both the similarities and differences between the world (or horizon) of the interpreting subject or community (i.e. reader) and the world of the interpreted Christian classics (i.e. text) are crucial. In short, from these examples it can be concluded that apart from the author, the fusion of horizons of the text and the reader is usually presupposed in contemporary hermeneutics.

${ }^{17}$ Text reception in this work supposes the dialectic of text and reader. On the one hand, the text controls the reader's response through its own strategies and conventions. On the other hand, the reader must actualise the world of the text in such a way as to be moved and enlightened by it. Thus, two foci come to the fore: (1) the question of how texts affect readers and (2) how readers respond to texts (and author) (cf Moyise 1998:53-54).

${ }^{18}$ A different but similar intention is Welzen's (1999:234) in which three steps of intertextual relations are investigated: (1) the syntax of intertextuality describes the intertextual relationships in terms of (non)transformation. (2) The semantics of intertextuality deals with the meaning and the function of these transformations and non-transformations. And (3) the pragmatics of intertextuality deals with the use of intertexts in the process of communication.

${ }^{19}$ To reread a "handbook" text is simply to seek greater clarity concerning a single, fully determinate meaning. However, to reread a "literary" text is to seek not clarity but resonances, intertextual allusions, new perspectives, transformed horizons. Here the greatest contribution of biblical criticism, frequently too readily dismissed by conservatives as wholly destructive, is to force us into an appreciation of the diversity of biblical texts and genres (Thiselton 1999:171).

${ }^{20}$ In the New Criticism (and prior to poststructuralism), a literary text was regarded as an autonomous, self-contained artifact; history, biography, and politics were completely ancillary to the issues of textuality and subsequent reading practices. The text was considered to exist separate from its author and cultural forces, and the text was regarded as transcending history and the author's subjectivity. In this regard, Ricoeur's (1991:298) argument is worth considering: a threefold autonomy of the text is (1) with respect to the intention of the author; (2) with respect to the cultural situation and all the sociological conditions of the production of the text; and (3) finally, with respect to the original addressee. Following in the wake of $\mathrm{J}$ Derrida, R Barthes, and other poststructural theories and philosophers, the supposed autonomy of the text was challenged; furthermore, a text was demonstrated to be a node within a larger nexus of social, historical, cultural, and textual forces, which not only changed the perceptions of textuality but also impacted on the way that a text was to be read. The rupturing of the autonomy of the text therefore initiated intertextual reading practices (Clippinger 2001:190; cf Culler 1983:103).

${ }^{21}$ In deconstructionism no meaning is recoverable from an original author's intentional acts of writing and the enterprise of interpretation is primarily the exposing of authors' or interpreters' triumphalistic presuppositions (Beale 1999a:162). For Moyise the concept of intertextuality is an umbrella term for the complex interactions that exist between "texts" (in the broadest sense). But he suggests three categories: intertextual echo, dialogical intertextuality, and postmodern intertextuality (see Moyise 2000:17, 34-37). With regard to the last category, namely, postmodern intertextuality, Moyise says that "by focusing on the need for individual interpreters to "produce meaning", it has much in common with those approaches broadly classed as deconstruction." As Moyise himself admits, however, for some, postmodern intertextuality, like deconstruction, will seem a pointless exercise, because the task of the 
interpreter is surely to grapple with a text until its meaning is disclosed, or more realistically, to get as close to that meaning as possible. In short, it seems that Moyise classes himself with more radical reader-oriented critics, because the approach with which he aligns himself generally contends that reader or interpretive communities are the ultimate determiners of a text's meaning and not the original author's intention in a text (cf Beale 1999a:180). In addition, Beardslee (1993:221) observes that "deconstructive criticism is a way of reading that involves both discovering the incompleteness of the text and finding a fresh, if transient, insight made possible by "the free play" or indeterminacy of the text". Deconstruction is not so much a radical novelty as a revival of an ancient and honourable tradition of skepticism. It draws its plausibility from the breakdown of virtually all theories of rationality and criticism (Champion, 1989:97). Here, the emphasis of indeterminacy is not compatible with the intertextuality in this work. But as Beardslee (1993:232) also admits, the presuppositions of deconstruction are not to be accepted uncritically. While deconstructive criticism starts neither with the present reader nor with an attempt to reconstruct a historical picture of an original meaning (Beardslee, 1993:229), intertextuality in this dissertation starts with John and his original audience. At this stage, the assessment of Thomas (1999:48-49) is pertinent: deconstructionism is a black hole, swallowing up all possibility of intended meaning. A text, which is intrinsically indeterminate, even self-contradictory, cannot really exert authority over its reader. To affirm that the Bible deconstructs itself is to strip it entirely of any authoritative status.

${ }^{22}$ In a book such as Revelation, where allusion is central to the imagery, the concepts of authorial intention and reader response come together. To put it another way, the author of an allusive text begins as reader of an earlier text. Exegetes cannot proclaim the death of the author without proclaiming the death of the reader, because every author is a reader as well. And conversely, if exegetes claim the existence of the reader, they must accept the author as well (Paulien 2001:21-22).

${ }^{23}$ There is another difference between French intertextual critics and American critics. Whereas Barthes and Kristeva refuse to allow the concepts of "author" or "source" to overlap with that of anonymous intertextuality, American theorists, as Jay Clayton and Eric Rothstein note, have questioned the firm boundaries between influence and intertextuality and even perceive these boundaries as virtually nonexistent (Landwehr 2002:4).

${ }^{24}$ Of course the reader attributes meaning to the text by the activity of reading, but at the same time s/he is guided by the data in the text. "The text of the reader" is the total of meanings constructed by the activity of the reader on the basis of the instructions given by the text (Welzen 1999:227).

${ }^{25}$ In this connection, "the text of the author" is the text made by the author, which has found its material expression in the written and oral product.

${ }^{26}$ Some scholars do not permit uncontrolled intertextual studies. One example is that of Culler (1983:118) who has two presupposions of intertextuality, that is, logical and pragmatic. He suggests two limited approaches to intertextuality: the first is to look at the specific presuppositions of a given text, the way in which it produces a pre-text, an intertextual space whose occupants may or may not correspond to other actual texts. The second enterprise, the study of pragmatic presupposition, leads to a poetics which is less interested in the occupants of that intertextual space which makes a work intelligible than in the conventions which underlie that discursive activity or space. Another example is that of Welzen (1999:233), according to whom there is a minimalistic and a maximalistic understanding of intertextuality. The minimalistic view considers as relevant only the architexts indicated in the fenotext by indicators. The maximalistic understanding sees intertextuality as a feature of every utterance. Every utterance has its home in a continually growing language system. This understanding leads to a never ending process of meaning by connecting the fenotext again and again to new and different intertexts. The maximalistic understanding is unmanageable because it is a hopeless task. So Welzen (1999:234) reaches the conclusion that a position in between is asked for. In this midway position a description of relationships of texts is possible in terms of transformation, including addition, deletion, transposition or replacement. 
${ }^{27}$ The NT writers lived in a world of communication. Communication among Christians in the first century was not that of isolated communities but of "the holy internet". For this reason, John the seer knew of the NT epistles and the Gospels and that, if he wished, he could get copies of them (cf Brodie 2001:108).

${ }^{28}$ According to Hepner (2001:5-22), lexical analogies creating verbal resonances fall into five main categories in the study of OT intertextuality. The five categories of resonance are: (1) repetition of identical word roots, (2) resonance of dissimilar words that share two consonants, (3) resonance of anagrams, (4) missing resonances, and (5) numerical resonances. It seems that even in NT intertextual analysis, exegetes can use verbal resonances to help identify intertextual links between biblical narratives.

${ }^{29}$ A dissenting voice comes from Brodie (2001:109), arguing that similarities of theme, though helpful, are not decisive, but similarities of motif, action, and details provide strong evidence. Thematic coherence, however, is still a useful criterion of intertextuality in Revelation (esp the Exodus theme).

${ }^{30}$ One of the most distinguished characteristics of reformed hermeneutics is its emphasis on the reality behind the text, namely God, the original Author of the Bible. Since God is the transcendent source of human rationality and the ultimate ground of linguistic meaning, God is capable of making his intentions known through a written text. Consequently, God's central purposes and intentions are accessible through a correct interpretation of Scripture. One who is interested in the truth will naturally have an interest in the realities behind the text. God is the ultimate cause of the text, and it is a means of knowing him (see Walls 1996:187-188). And as Moroney (1999:450) points out, the recognition of effects of sin on scholarship is also an important presupposition of reformed hermeneutics.

${ }^{31}$ Combrink (1990:339), McQuilkin and Mullen $(1997: 71,82)$ rightly reason that the impact of postmodern thinking on reformed (or evangelical) Bible interpretation is profound, both for understanding eternal, unchanging truth and for applying that truth to Christian lives today. On the one hand, postmodern hermeneutical methodologies present reformed (evangelical) scholars with serious challenges at three points, among others: (1) unchanging, ultimate truth does not exist; (2) language cannot accurately communicate thought to another person's mind; and (3) the inadequacy of language is not necessarily bad because meaning is constituted of a combination of what is out there (objects and events, including the words of others) and what is in here (exegete's subjective sense). On the other hand, postmodern thinking provides reformed scholars with unprecedented opportunities. There are some legitimate contributions from postmodern thinking. For example, it alerts reformed exegetes to issues that they have not sufficiently addressed. As a result, they have to examine more carefully their own cultural and theological preunderstanding and are more modest in their claims to infallible interpretations.

${ }^{32}$ As Punt (1998:124-125) notes, some refer to the current interpretive landscape of NT studies as pluralist and describe the quest for the allusive meaning in NT interpretation as a war, and as a continuous fighting between different interpretive strategies. Unfortunately, increasing attention has been paid to the language, the literary forms, the symbols, myths, and stories in the Bible ( $\mathrm{i}$ e to methodology) rather than to theology in the Bible (i e to contenttheological results). Thus, many NT scholars display "methodolomania" and contribute to the proliferation of methods.

${ }^{33}$ Like Combrink, Phillips (1990:36) holds that the postmodern context compels a recognition of interpretive control and power that is exercised, whether exegetes care to admit it or not. The present context for engaging in critical exegetical praxis opens up before exegetes an opportunity for re-energising a discipline that has the opportunity and the responsibility of defining a new discursive context.

${ }^{34}$ Correspondingly, Barton $(1994: 3,14)$ also contends that biblical studies at the moment illustrate clearly the phenomenon structuralists used to be so interested in, the binary opposition, and a few such pairs will be enough to identify the two trends involved: diachronic 
vs synchronic; historical vs. literary theory; what the text means vs. what the text means (or what readers may mean by it). Deliberate collaboration between historical critics and literary interpreters can be useful, because most biblical texts need both historical and literary skill if they are to be adequately interpreted.

${ }^{35}$ Along with Vanhoozer, Morgan (1985:13) observes that the notion of intertextuality apparently swings between the constructive and the deconstructive: on the one hand, it can be used to support the claim that intertextuality adequately accounts for the structure, meaning and function of all sorts of texts. On the other hand, it can furnish ammunition for an attack on the very idea of the "sign" by focusing exegetes' attention on the indeterminacy of meaning produced by the free play of "signifiers" among numerous texts - as in Derrida. With regard to the concept of canon, for the reformed intertextual study, the view on the Bible is crucial. The text of the Bible, as a living unity, consists of texts, smaller units, and sequences of texts written down, eventually encompassing both the OT and the NT and growing into one canonical text. This historically grown unity is the living Bible believers all over the world live by from day to day (cf Van Huyssteen 1997:156). Indeed, intertextual study is useful in biblical studies, the Bible is not necessarily viewed as a severely gapped text (contra Wall 2001:217).

${ }^{36}$ No determinate meaning is linked with the typical postmodern condition, which is described with terms "radical, often conflicting, plurality of ever particular discourses and narratives"; postmodernity is contained in the triad "conflict", "indeterminant plurality" (or irreducible heterogeneity) and "particularity" (or contextuality) (cf Boeve 1997:408, 425). Postmodernism accepts inderterminacy, polyvalence and subjectivity as necessary elements in the study of a reality. In the notion of intertextuality, the reader too is intertextual, that is, not an autonomous Cartesian ego but a potentiality arising from a cultural context. In postmodern intertextuality the reader is no more autonomous than the text. Reader and text are interdependent. The notion of reader's competence (i e the intertextual awareness and linguistic and cultural abilities of reader) can be used in a postmodern sense, referring to the range of abilities and concerns that enable a reader to actualise a text in a way that is unique, valid and highly subjective. On the contrary, in the reformed intertextuality embedded in modernist orientation, the reader's role is clearly defined by the text. Text is the object with determinate meaning. Readers are those who, if they follow the directives of the text, will arrive at its determinate meaning (see Keegan 1995:4-5). As far as the focal method of this work - intertextuality - is concerned, the main difference between its use in the present work and in a postmodern exegesis is that the latter emphasises the "undecidability" of the text, but the former stresses the "pluri-decidability" (in D Patte's term, see Patte 1995:67) of the text (due to Revelation's pragmatic and symbolic characteristics).

${ }^{37}$ Lategan (1992b:9) correctly argues that giving due recognition to the reader-mediated nature of texts does not mean that they thereby lose their identity, completely subjected to the whim of interpreters. For an example of the interaction between intertextuality and readerresponse criticism (in James 2:25), see Wall 2001:223.

${ }^{38}$ Zepp (1982:90), following Kristeva, holds that texts are at least doubly oriented: toward an "inner" meaning (the web of the signifying system in question: i e intratextual meaning) and an "outer" meaning (the discourse with other discourses, with social process: i e, intertextual meaning), which are in dialogical relationship with each other. The interaction among the author, the text, and the reader in intertextuality is not new. According to Gadamer, interpretation is always the fusion of horizons. Both the text (and author) and the interpreter have a horizon that includes everything that can be seen from a particular vantage point. But every act of interpretation transforms the horizon of both the text and the interpreter (see Gadamer 2001:302-307).

${ }^{39}$ Fowler (1989:4) explains that intertextuality, indeterminacy, and combination are characteristics of postmodernism, as genre/boundary, determinacy, and selection are of modernism.

${ }^{40}$ Some scholars, who are embedded in the diachronic interpretation, try to keep a balance between diachronic and synchronic aspects in the study of intertextuality. Schoors (2000:59), 
for instance, argues that "in order to understand an actual text, synchronic reading is indispensable, but in order to give to the text its full depth, a study of the antecedents of the borrowed material, i e its trajectory from the source text to the final text, is also indispensable and is more promising than an approach which simply takes all texts of a corpus or even of several corpora as synchronic. Basically biblical science has to work with controllable data and verifiable statements; otherwise it no longer exists as a science". Correspondingly, Barton (2000:36) insists that the current conjunction between "final form" exegesis (i e synchronic) and "holistic" (that is, reading the text in its final form as an aesthetic or communicative unity) interpretation is accidental rather than necessary. Rabbinic interpretation, which pays no attention at all to diachronic questions about how a text came to be and in that sense concentrates entirely on the final form, clearly shows that it is possible for the two to be dissociated.

${ }^{41}$ As Kruger (1995:108) points out, biblical scholars in general were seduced by positivism and a method monism which reduced and ultimately distorted the complex phenomenon of textual communication to one mode or dimension. Therefore, a lack in method often reveals itself in a one-mode approach which leads to a one-sided over- or underexposure of texts. The crisis with regard to the interpretation of the NT texts is to a large extent the result of the lack of a comprehensive hermeneutical and exegetical theory. This is not only responsible for the over-interpretation and one-dimensional approach to the NT (i.e. a lack in methodology), but also for an uncritical awareness of the problems that science faces (i.e. a lack in theory; see Rousseau 1986:19, 23).

\section{Works Consulted}

Adam, A K M 1990. Biblical theology and the problem of modernity: Von Wredestrasse zu sackgasse. HBT 12, 1-18.

Aichele, G \& Phillips, G A 1995. Introduction: Exegesis, eisegesis, intergesis. Semeia, 69-70, 7-18.

Aune, D E 1991. Intertextuality and the genre of the Apocalypse, 142-160. (SBL Seminar Papers.)

Bakhtin, M M 1981. The dialogic imagination: Four essays by M M Bakhtin, ed by M Holquist, and tr by C Emerson \& M Holquist. Austin, TX: University of Texas Press.

Barthes, R 1977. The death of the author, and from work to text, in Images-musictext, 142-148, 155-164. Essays selected and translated by S Heath. London: Fontana.

Barthes, R 1981. Theory of the text, in Young, R, (ed), Untying the text: A poststructuralist reader, 31-47. Boston, MA: Routledge \& Kegan Paul.

Barton, J 1994. Historical criticism and literary interpretation: Is there any common ground?, in Porter, S E, Joyce, P \& Orton, D E, (eds), Crossing the boundaries: Essays in biblical interpretation in honour of Michael D Goulder, 3-15. Leiden: Brill.

Barton, J 2000. Intertextuality and the "final form" of the text, in Lemaire, A \& Sæbø, M, (eds), Congress volume: Oslo 1998:33-37. Leiden: Brill.

Beal, T K 1992. Glossary, in Fewell, D N, (ed), Reading between texts: Intertextuality and the Hebrew Bible, 21-24. Louisville, KY: Westminster John Knox.

Beale, G K 1998. John's use of the Old Testament in Revelation. Sheffield: Sheffield Academic Press. 
Beale, G K 1999. Questions of authorial intent, epistemology, and presuppositions and their bearing on the study of the Old Testament in the New: A rejoinder to Steve Moyise. IBS 21, 158-186.

Beale, G K 2001. A response to Jon Paulien on the use of the Old Testament in Revelation. AUSS 39(1), 23-34.

Beardslee, W A 1993. Poststructuralism, in Haynes, S R \& McKenzie, S L, (eds), To each its own meaning: an introduction to biblical criticisms and their application, 345-369. Louisville, KY: Westminster John Knox.

Boeve, $L$ 1997. Postmodernism and negative theology: The a/theology of the "open narrative". Bijdragen 58, 407-425.

Boyarin, D 1987. Old wine in new bottles: Intertextuality and Midrash. PT 8/3-4, 539556.

Brawley, $R$ L 1993. An absent complement and intertextuality in John 19:28-29. JBL 112(3), 427-443.

Brawley, R L 1995. Text to text pours forth speech: Voices of Scripture in Luke-Acts. Bloomington, IN: Indiana University Press.

Brawley, R L 2002. Contextuality, intertextuality, and the hendiadic relationship of promise and law in Galatians. ZNW 93(1/2), 99-119.

Brodie, T L 2001. Towards tracing the Gospel's literary indebtedness to the Epistles, in MacDonald, D, (ed), Mimesis and intertextuality in antiquity and Christianity, 104-116. Harrisburg, PA: Trinity.

Carroll, R P 1993. Intertextuality and the book of Jeremiah: Animadversions on text and theory, in Exum, J C \& Clines, D J A (eds), The new literary criticism and the Hebrew Bible, 55-78. Sheffield: Sheffield Academic Press.

Champion, R 1989. Toward constructive reconstruction. CR 3(1), 77-89.

Chandler, D 2002. Semiotics for beginners: Intertextuality. http://www.aber.ac.uk/media/documents/s4b/sem09.html. (Date of access: 6 August 2002.)

Combrink, H J B 1990. Die krisis van die Skrifgesag in die gereformeerde eksegese as 'n geleentheid. NGTT 31(3), 325-335.

Conradie, E 1992. What is an analogical imagination? SAJP 11(4), 103-112.

Craffert, P F 1996. Relationships between social-scientific, literary, and rhetorical interpretation of texts. BTB 26, 45-55.

Culler, J 1983. The pursuit of signs: Semiotics, literature, deconstruction. London: Routledge \& Kegan Paul.

Davis, S J 2002. Crossed texts, crossed sex: Intertextuality and gender in early Christian legends of holy women disguised as men. JECS 10(1), 1-36.

Degenaar, J 1995. The text is an episode in an all-encompassing textuality, 3-21. Bloemfontein: University of Orange Free State. (Acta Academica, Suppl 1.)

Derrida, J 1976. Of grammatology, translated by G C Spivak. Baltimore, MD: The Johns Hopkins University Press.

Desrosiers, G 2000. An introduction to Revelation: A pathway to interpretation. London: Continuum.

Du Toit, A B 1990. Die toekoms van die Skrifgesag in die moderne eksegese: 'n Hoofsaaklik Nuwe-Testamentiese perspektief. NGTT 31(4), 509-519.

Erickson, M J 1993. Evangelical interpretation: Perspectives on hermeneutical issues. Grand Rapids, MI: Baker. 
Fishbane, M 1985. Biblical interpretation in ancient Israel. Oxford : Oxford University Press.

Fowler, R M 1989. Postmodern biblical criticism. Forum 5(3), 3-30.

Fox, N 2002. Intertextuality and the writing of social research. http://www.icaap.org/iuicode?100.1.2.1 (Date of access: 6 August 2002.)

Gadamer, H G 2001. Truth and method, 2nd ed tr by J Weinsheimer \& D G Marshall. London: Sheed \& Ward.

Glodo, M J 2000. The Bible in stereo: New opportunities for biblical interpretation in an a-rational age, in Dockery, D S (ed), The challenge of postmodernism: An evangelical engagement, 148-172. Grand Rapids, MI: Baker.

Greimas, A J \& Courtés, J 1979. Intertextuality, in Greimas, A J \& Courtés, J (eds), Semiotics and language: An analytical dictionary, 160-161. Bloomington, IN: Indiana University Press.

Grenz, S J 2000. Beyond foundationalism: Is a nonfoundationalist evangelical theology possible? CSR 30(1), 57-82.

Gulley, N R 2000. Reader-response theories in postmodern hermeneutics: A challenge to evangelical theology, in Dockery, D S (ed), The challenge of postmodernism: An evangelical engagement, 208-238. Grand Rapids, MI: Baker.

Harty, E R 1985. Text, context, intertext. JLS 1(2), 1-13.

Hatina, T R 1999. Intertextuality and historical criticism in New Testament studies: Is there a relationship? BI 7(1), 28-43.

Hays, R B 1989. Echoes of Scripture in the letters of Paul. New Haven, CT: Yale University Press.

Heie, H 1996. The postmodern opportunity: Christians in the academy. CSR 26(1), 138-157.

Hepner, G 2001. Verbal resonance in the Bible and intertextuality. JSOT 96, 3-27.

Jenny, L 1982. The strategy of form, in Todorov, T (ed), tr by R Carter, French literary theory today: A reader, 34-63. Cambridge: Cambridge University Press.

Keesmaat, S 1994. Exodus and the intertextual transformation of tradition in Romans 8:14-30. JSNT 54, 29-56.

Kristeva, J 1982. Psychoanalysis and the polis, tr by M Waller. Cl 9, 77-92.

Kristeva, J 1984. Revolution in poetic language. New York: Columbia University Press.

Kristeva, J 1986. The Kristeva reader, ed by T Moi. New York: Columbia University Press.

Kruger, M A 1995. Die bydrae en relevansie van die Nuwe Testamentiese wetenskap in die GKSA 1896-1994. In die Skriflig 29(1\&2), 95-116.

Lategan, B C 1992. The reception of reception theory in South Africa, in Lategan, B (ed), The reader and beyond, 1-11. Pretoria: HSRC.

Linton, G L 1993. Intertextuality in the Revelation of John. Ann Arbor: UMI.

Mangis, M W 1999. Al alien horizon: The psychoanalytic contribution to a Christian hermeneutic of humility and confidence. CSR 28(3), 411-431.

Mcquikin, R \& Mullen, B 1997. The impact of postmodern thinking on evangelical hermeneutics. JETS 1997, 69-82. 
Mertens, A 1990. Intertekstualiteit in Mertens, A \& Beekman, K (eds), Intertekstualiteit in theorie en praktijk, 1-24. Dordrecht: Foris Publications.

Mettinger, T N D 1993. Intertextuality: Allusion and vertical context systems in some Job passages, in McKay, H A \& Clines, D J A, (eds), Of prophet's visons and the wisdom of sages: Essays in honour of $R$ Norman Whybray on his seventieth birthday, 257-280. Sheffield: JSOT Press.

Morgan, T E 1985. Is there an intertext in this text?: Literary and interdisciplinary approaches to intertextuality. AJS 3(4), 1-40.

Moroney, S K 1999. How sin affects scholarship: A new model. CSR 28(3), 432451.Mouton, J 2002. How to succeed in your master \& doctoral studies: $A$ South African guide and resource book. Pretoria: Van Schaik Publishers.

Moyise, S 1995. The Old Testament in the Book of Revelation. Sheffield: Sheffield Academic Press.

Moyise, S 1998. Introduction to biblical studies. London: Cassell.

Moyise, S 2000. Intertextuality and the study of the Old Testament in the New, in Moyise, S (ed), The Old Testament in the New Testament: Essays in honour of $\mathrm{L}$ L North, 14-41. Sheffield: Sheffield Academic Press.

Moyise, S 2001. Authorial intention and the Book of Revelation. AUSS 39(1), 35-40.

Nielsen, K 2000. Intertextuality and Hebrew Bible, in Lemaire, A \& Sæbø, M, (eds), Congress volume: Oslo 1998:17-31. Leiden: Brill.

Patte, D 1995. Ethics of biblical interpretation: A reevaluation. Louisville, KY: Westminster John Konx.

Paul, I 2000. The use of the Old Testament in Revelation 12, in Moyise S, (ed), The Old Testament in the New Testament: Essays in honour of $J$ L North, 256276. Sheffield: Sheffield Academic Press.

Paulien, J 2001. Dreading the whirlwind intertextuality and the use of the Old Testament in Revelation. AUSS 39(1), 5-22.

Perrin, N 1983. Apocalyptic Christianity, in Hanson, P D, (ed), Visionaries and their apocalypses, 121-145. Philadelphia, PA: Fortress.

Phillips, G A 1990. Exegesis as critical praxis: Reclaiming history and text from a postmodern perspective. Semeia 51, 7-49.

Phillips, G A 1991. Sign/text/différance: The contribution of intertextual theory to biblical criticism, in Plett, H F (ed), Intertextuality, 78-97. Berlin: Walter de Gruyter.

Plantinga, A 1983. Reason and belief in God in Plantinga, A \& Wolterstorff, N (eds), Faith and Rationality: reason and belief in God, 16-93. Notre Dame, IN: University of Notre Dame Press.

Plett, H F 1991. Intertextualities, in Plett, H F (ed), Intertextuality, 3-29. Berlin: Walter de Gruyter.

Polaski, D C 1998. Reflections on a Mosaic covenant: The eternal covenant (Isaiah 24:5) and intertextuality. JSOT 77, 55-73.

Poythress, V S 1999. God centered biblical interpretation. Phillipsburg, NJ: P \& R Publishing.

Punt, J 1998. New Testament interpretation, interpretive interests, and ideology: Methodological deficits admists South African methodolomania? Scriptura 65, 123-152. 
Rajan, T 1991. Intertextuality and the subject of reading/writing, in Clayton, J \& Rothstein, E, (eds), Influence and intertextuality in literary history, 61-74. Wisconsin, NC: The University of Wisconsin Press.

Ricoeur, P 1984. Time and narrative, Vol 1. Chicago, IL: University of Chicago Press.

Ricoeur, P 1991. From text to action: Essays in hermeneutics, II, tr by K Blamey, \& J B Thompson, London: The Athlone Press.

Riffaterre, M 1987. The intertextual unconscious. $\mathrm{Cl}$ 13, 371-385.

Riffaterre, M 1990. Compulsory reader response: the intertextual drive, in Worton, $M$ \& Still, J (eds), Intertextuality: Theories and practices, 56-78. Manchester: Manchester University Press.

Rousseau, J 1986. A multidimensional approach towards the communication of an ancient canonized text: Towards determining the thrust, perspective and strategy of 1 Peter. DD dissertation, University of Pretoria.

Ryan, R 1985. Pathologies of epistemology in literary studies. JLS 1(1), 3-42.

Sanders, J A 2000. Intertextuality and dialogue. BTB 30(1), 35-44.

Sanders, J A 2001. Canon as dialogue, in Flint, P W (ed), The Bible at Qumran: Text, shape, and interpretation, 7-26. Grand Rapids, MI: Eerdmans.

Schoors, A 2000. (Mis)use of intertextuality in Qoheleth exegesis, in Lemaire, A \& Sæbø, M (eds), Congress volume: Oslo 1998:45-59. Leiden: Brill.

Senekal, A 1999. Towards a Christ-centred sociology: An envisioned ideal. Koers 64(1), 65-81.

Silva, M 1994. The New Testament use of the Old Testament: Text form and authority, in Carson, D A \& Woodbridge, J D, (eds), Scripture and truth, 147165. Grand Rapids, MI: Baker.

Soulen, R N \& Soulen, R K 2001. Handbook of biblical criticism: Now includes precritical and postcritical interpretation. Louisville, KY: Westminster John Knox.

Thiselton, A C 1992. New horizons in hermeneutics: The theory and practice of transforming biblical reading. Grand Rapids, MI: Zondervan.

Thiselton, A C 1999. Communicative action and promise in interdisciplinary, biblical, and theological hermeneutics, in Lundin, R, Walhout, C \& Thiselton, A C, (eds), The promise of hermeneutics, 133-239. Grand Rapids, MI: Eerdmans.

Thomas, B 1989. The new historicism and other old-fashioned topics, in Veeser, H A (ed), The new historicism, 182-203. New York: Routledge.

Thomas, G J 1999. Telling a hawk from a handsaw?: An evangelical response to the new literary criticism. EvQ 71(1), 37-50.

Vanhoozer, $\mathrm{K} \mathrm{J}$ 1998. Is there a meaning in this text?: The Bible, the reader, and the morality of literary knowledge. Grand Rapids, MI: Zondervan.

Van Huyssteen, J W 1997. Essays in postfoundationalist theology. Grand Rapids, MI: Eerdmans.

Van Wolde, E 1997. Intertextuality: Ruth in dialogue with Tamar, in Brenner, A \& Fontaine, C (eds), A feminist companion to reading the Bible: Approaches, methods and strategies, 426-451. Sheffield Academic Press: Sheffield.

Voelz, J W 1995. Multiple signs, levels of meaning and self as text: Elements of intertextuality. Semeia 69 \& 70, 149-164.

Vorster, W S 1988. "Genre" and the Revelation of John: A study in text, context and intertext. Neot 22(1), 103-123. 
Vorster, W S 1993. The production of the Gospel of Mark: An essay on intertextuality. HTS 49(3), 385-396.

Wall, R W 2000. Biblical intertextuality, in Evans, C A \& Porter, S (eds), Dictionary of New Testament background, 541-551. Leichester: IVP.

Wall, R W 2001. The intertextuality of Scripture: The example of Rahab (James 2:25), in Flint, P W (ed), The Bible at Qumran: Text, shape, and interpretation, 217-236. Grand Rapids, MI: Eerdmans.

Walls, J 1996. The flight from truth in New Testament scholarship. CSR 25(4),180196.

Zepp, E H 1982. The criticism of Julia Kristeva: A new mode of critical thought. RR 73, 80-97. 